\title{
250 Ma metagranitoid from Drangovo Village: a new discovery of Permo-Triassic magmatism in the Eastern Rhodopes, Bulgaria
}

\author{
Peter Marchev, Stoyan Georgiev, Raya Raicheva, Milan Ichev \\ Geological Institute, Bulgarian Academy of Sciences, Acad. G. Bonchev Str., bl. 24, 1113 Sofia, Bulgaria; \\ e-mail: pmarchev@geology.bas.bg
}

(Accepted in revised form: April 2019)

\begin{abstract}
This short communication reports a $251.4 \pm 6.8$ Ma age of a Permo-Triassic metagranitoid (augen gneiss) in the Bulgarian part of the Eastern Rhodopes. The rock is intruded by the early Eocene Drangovo pluton and represents part of the upper metamorphic unit of the Kessebir dome. The analyzed sample has slightly peraluminous (ASI $=1.11$ ) granitic composition with $\mathrm{SiO}_{2}=70.6 \mathrm{wt}$.\%. It is enriched in LILE and LREE and depleted in HREE, with a deep Eu $\left(\mathrm{Eu}^{\mathrm{E}} \mathrm{Eu}^{*}=0.49\right)$ anomaly consistent with garnet and plagioclase fractionation. The large number of xenocrystic zircons, along with the low $\left(780^{\circ} \mathrm{C}\right)$ crystallization temperature and petrochemical data, suggests significant assimilation of basement rocks by the granitic magma. The rock has a subduction-related signature.
\end{abstract}

Marchev, P., Georgiev, S., Raicheva, R., Ichev, M. 2019. 250 Ma metagranitoid from Drangovo Village: a new discovery of Permo-Triassic magmatism in the Eastern Rhodopes, Bulgaria. Geologica Balcanica 48 (1), 63-71.

Keywords: Permo-Triassic magmatism, U-Pb zircon age, augen gneiss, subduction-collision, Eastern Rhodopes.

\section{INTRODUCTION}

Triassic and Permo-Triassic (P-T) magmatic and metamagmatic rocks are relatively common in the Serbo-Macedonian Massif but very rare in the Rhodope Massif. Recent studies of this magmatism support two fundamentally different views on its genesis and tectonic significance. In the Serbo-Macedonian Massif, one group of authors considers this magmatism as anorogenic and hence rift-related (Christophides et al., 1999; Himmercus et al., 2009; Bonev et al., 2018). A second group of authors regards the magmatism as A-2 type, which formed in a post-orogenic extensional environment, rather than in an anorogenic within-plate environment (Poli et al., 2009), or as representing an island-arc/ continental margin or a post-collisional geodynamic environment (Zidarov et al., 2007; Peytcheva et al., 2009). In the Central Rhodopes, this magmatism is almost unknown except for the 210-240 Ma age obtained from multigrain zircon fraction from gneisses in the vicinity of Shiroka Laka Village (Arnaudov et al., 1998), and metamorphosed diorites from the Arda Unit east of the Rila-Rhodope batholith that yielded a discordia with an upper intercept age of $253 \pm 13$ Ma (von Quadt and Peytcheva, 2005). Until recently, P-T magmatism had not been identified in the Eastern Rhodopes. The first report for such magmatic rocks was the paper of Drakoulis et al. (2013) for the Papikion pluton (Greece), located in the south part of the Kessebir-Kardamos dome, close to the Bulgarian-Greek border. The Papikion pluton consists of six non-foliated or slightly foliated rock types: hornblende diorite, biotite hornblende diorite, hornblende granodiorite, biotite hornblende granodiorite, biotite granodiorite, biotite granite, as well as aplitic dikes intruding the six major rock types above.

This short communication reports the results of in situ zircon $\mathrm{U}-\mathrm{Pb}$ age dating and chemistry of a newly found P-T metagranitoid (augen gneiss) in the Bulgarian part of the Eastern Rhodopes, close to Drangovo Village and only $20 \mathrm{~km}$ from Papikion pluton. We conclude that the P-T magmatism in 
the Rhodope Massif had a wide distribution, thus resembling P-T magmatic activity in the SerboMacedonian Massif.

\section{GEOLOGICAL BACKGROUND AND SAMPLING}

The metagranitoid is located in the south-westernmost part of the Kessebir-Kardamos dome in the Eastern Rhodopes (Fig. 1). It forms part of the metaigneous and metasedimentary rocks of the Upper Unit of the metamorphic basement, which is mainly composed of Ordovician ( 455 Ma; Bonev et al., 2013) metamafic-ultramafic ophiolites with a MORB-IAT signature, and marbles and Jurassic plagiogranites ( 159 Ma; Peytcheva et al., 1998). The metagranitoid body in Fig. 1 is included within the frame of a parametamorphic unit, the biotite gneiss of the Borovitsa lithotectonic unit (Sarov et al., 2008). The studied area is southeast of the contact with the early Eocene (50 Ma) Drangovo pluton, which intrudes the metagranitoid (Marchev et al., 2013, Raicheva et al., 2018). Surface outcrops of the metagranitoid are strongly deformed fine-grained, almost mylonitic rocks, confirmed by microscopic observations of two samples. Sample Dr17-2 (coordinates N41.35041º, E25.25954ㅇ) was taken after careful selection in the field because of its relatively more preserved porphyritic texture. The outcrop is about $60 \mathrm{~m}$ from the contact with the Drangovo pluton (Fig. 1), but it falls in the frame of the pluton on the map of Sarov et al. (2008).

\section{ANALYTICAL PROCEDURES}

Whole-rock major and a limited number of trace elements were measured by Thermo ARL Perform' $X$ WDXRF spectrometer at Hamilton College (USA) and calibrated against both international and internal standards. A larger set of whole rock trace elements were determined on freshly broken crosssections of the fused pellets, using the laser ablation system New Wave UP193FX coupled with an ICPMS PerkinElmer ELAN DRC-e at the Geological

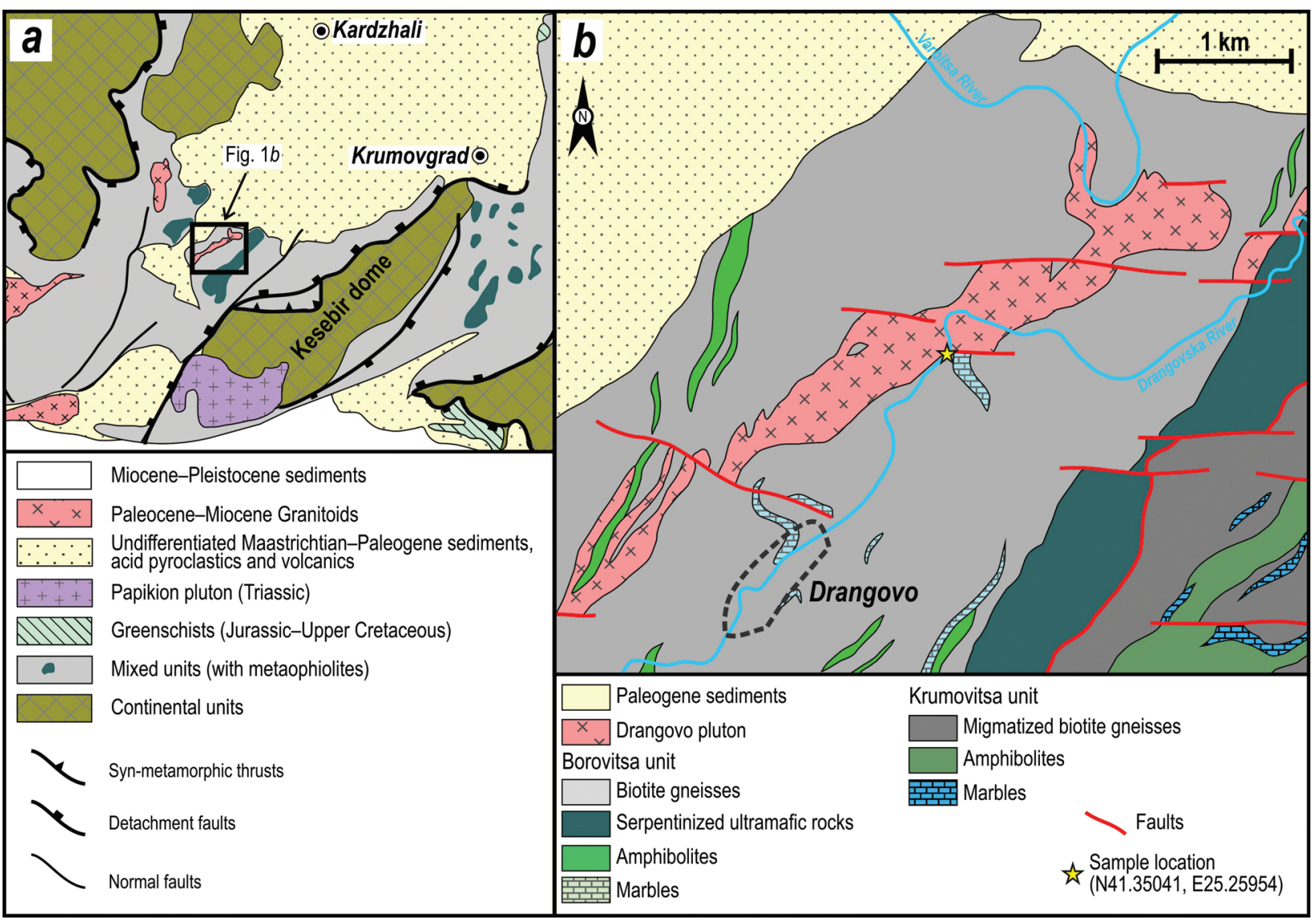

Fig. 1. a) Map of the Kessebir dome and surrounding area after Ricou et al. (1998); $b$ ) Simplified geological map of the Drangovo pluton after Nedialkov et al. (1998) and Sarov et al. (2008). 
Table 1

Major and trace element data for the Drangovo metagranitoid (Sample D17-2)

\begin{tabular}{cccccccccccccccccccccccc}
\hline $\mathrm{SiO}_{2}$ & $\mathrm{TiO}_{2}$ & $\mathrm{Al}_{2} \mathrm{O}_{3}$ & $\mathrm{FeO}$ & $\mathrm{MnO}$ & $\mathrm{MgO}$ & $\mathrm{CaO}$ & $\mathrm{Na}_{2} \mathrm{O}$ & $\mathrm{K}_{2} \mathrm{O}$ & $\mathrm{P}_{2} \mathrm{O}_{5}$ & $\mathrm{LOI}$ & $\mathrm{Total}$ & $\mathrm{Sc}$ & $\mathrm{V}$ & $\mathrm{Cr}$ & $\mathrm{Co}$ & $\mathrm{Ni}$ & $\mathrm{Zn}$ & $\mathrm{Cu}$ & $\mathrm{Pb}$ & $\mathrm{Ga}$ & $\mathrm{Zr}$ & $\mathrm{Hf}$ \\
\hline 70.56 & 0.356 & 14.14 & 1.91 & 0.03 & 0.72 & 1.36 & 3.16 & 4.72 & 0.171 & 2.53 & 99.65 & 12.2 & 35.2 & 6 & 1.97 & 4.39 & 41 & 3.88 & 24.2 & 22 & 143 & 4.03 \\
\hline $\mathrm{Nb}$ & $\mathrm{Ta}$ & $\mathrm{U}$ & $\mathrm{Y}$ & $\mathrm{Th}$ & $\mathrm{Rb}$ & $\mathrm{Cs}$ & $\mathrm{Sr}$ & $\mathrm{Ba}$ & $\mathrm{La}$ & $\mathrm{Ce}$ & $\mathrm{Pr}$ & $\mathrm{Nd}$ & $\mathrm{Sm}$ & $\mathrm{Eu}$ & $\mathrm{Gd}$ & $\mathrm{Tb}$ & $\mathrm{Dy}$ & $\mathrm{Ho}$ & $\mathrm{Er}$ & $\mathrm{Tm}$ & $\mathrm{Yb}$ & $\mathrm{Lu}$ \\
\hline 8.81 & 0.79 & 3.35 & 9.75 & 16.3 & 133 & 0.84 & 221 & 878 & 45.89 & 93.42 & 10.63 & 41.13 & 7.31 & 0.93 & 5.09 & 0.51 & 2.24 & 0.31 & 0.83 & 0.11 & 0.55 & 0.07 \\
\hline
\end{tabular}

Institute of BAS, Sofia. We used a 100- $\mu$ laser beam diameter and $10 \mathrm{~Hz}$ repetition rate. NIST 610 glass was used for an external calibration standard, and the $\mathrm{XRF} \mathrm{SiO}_{2}$ value was used as the internal standard and for cross-checking. The analysis is given in Table 1.

Cathodoluminescence (CL) images were taken in the Belgrade University prior to zircon analyses to identify inherited cores, cracks and inclusions. $\mathrm{U}-\mathrm{Pb}$ isotope analyses of particular zircon zones were carried out, using the same LA-ICP-MS system at the Geological Institute, Bulgarian Academy of Science. Both rims and cores of the zircon crystals were analyzed to determine the magmatic crystallization age and the ages of the xenocrystic or/and inherited components. Spatial resolution was $35 \mu \mathrm{m}$ with a frequency of $8 \mathrm{~Hz}$. The measurement procedure involved calibration against an external zircon standard (GEMOC GJ-1) at the beginning, middle and at the end of the analytical block. This technique allows a suitable correction for instrumental drift along with the minimization of elemental fractionation effects. Raw data were processed using GLITTER4, a data reduction program of GEMOC, Macquarie University, Australia. ${ }^{207} \mathrm{~Pb} /{ }^{206} \mathrm{~Pb},{ }^{208} \mathrm{~Pb} /{ }^{232} \mathrm{Th},{ }^{206} \mathrm{~Pb} /{ }^{238} \mathrm{U}$ and ${ }^{207} \mathrm{~Pb} /{ }^{235} \mathrm{U}$ ratios were calculated and the time-resolved ratios for each analysis were then carefully examined. Optimal signal intervals for the background and ablation data were selected for each sample and automatically matched with the standard zircon analyses. U-Pb Concordia ages were calculated and plotted using ISOPLOT (Ludwig, 2003).

\section{PETROGRAPHY}

The rock has a porphyroclastic texture (augen gneiss), consisting of up to $2 \mathrm{~cm} \mathrm{~K}$-feldspar augen (Fig. 2a) with quartz, lesser amounts of plagioclase, and white mica predominating over biotite. K-feldspar shows internal deformation expressed by undulatory extinction in the core, rimmed with a vermicular (myrmekite) intergrowth of quartz and plagioclase (Fig. 2b). Most of the quartz is also undulose. The deformation-induced transition through equigranular to banded augen orthogneiss is evident in mylonitic gneiss varieties. Micas show preferred orientation aligned parallel to the foliation of the rocks (Fig. 2c). Chlorite is a common secondary mineral replacing biotite. Small carbonate patches replace K-Feldspar in the most deformed samples, whereas plagioclase is slightly sericitized. Along with rare pyrite, they suggest slight hydrothermal alteration. Accessories include apatite, zircon and allanite, sometimes rimmed by magmatic epidote (Fig. 2d).

\section{WHOLE-ROCK MAJOR AND TRACE ELEMENT GEOCHEMISTRY}

As shown in Table 1, the rock has a felsic composition with $\mathrm{SiO}_{2} 70.6$ wt.\% and a high content of $\mathrm{K}_{2} \mathrm{O}$ (4.7 wt.\%) and $\mathrm{Na}_{2} \mathrm{O}$ (3.2 wt.\%). The A/CNK ratio [molecular $\mathrm{Al}_{2} \mathrm{O}_{3} /\left(\mathrm{CaO}+\mathrm{Na}_{2} \mathrm{O}+\mathrm{K}_{2} \mathrm{O}\right)$ ] of 1.11 classifies the rock as an S-type granite, but very close to the S-type - I-type boundary (Fig. 3a). It has a steep chondrite-normalized pattern with high light REE and low heavy REE (Fig. 3b). The total content of REE is high ( 210 ppm). The high $\mathrm{La}_{\mathrm{N}} / \mathrm{Yb}_{\mathrm{N}}$ and $\mathrm{Dy}_{\mathrm{N}} / \mathrm{Yb}_{\mathrm{N}}$ ratios (58.9 and 2.7, respectively) are consistent with significant garnet fractionation, whereas the strong negative $\mathrm{Eu} / \mathrm{Eu}^{*}=$ 0.49 anomaly suggests extensive plagioclase fractionation. The primitive mantle normalized pattern (Fig. $3 b$ ) of the metagranitoid is slightly enriched in many of the most incompatible elements including $\mathrm{Th}, \mathrm{U}, \mathrm{Rb}, \mathrm{K}$ and $\mathrm{Pb}$, and markedly depleted in $\mathrm{Nb}, \mathrm{Ta}, \mathrm{Ti}, \mathrm{Sr}$ and $\mathrm{P}$ (Fig. $3 b$ ), resembling patterns typical for evolved orogenic rocks.

A prominent feature of the rock is its low HREE and $\mathrm{Y}$ content $(0.56 \mathrm{ppm} \mathrm{Yb}$ and $9.8 \mathrm{ppm} \mathrm{Y}$ ). The rocks display elevated $\mathrm{Sr} / \mathrm{Y}$ (22.7) and $\mathrm{La} / \mathrm{Yb}$ (82.8) ratios, which classifies them as adakite-like rocks. 

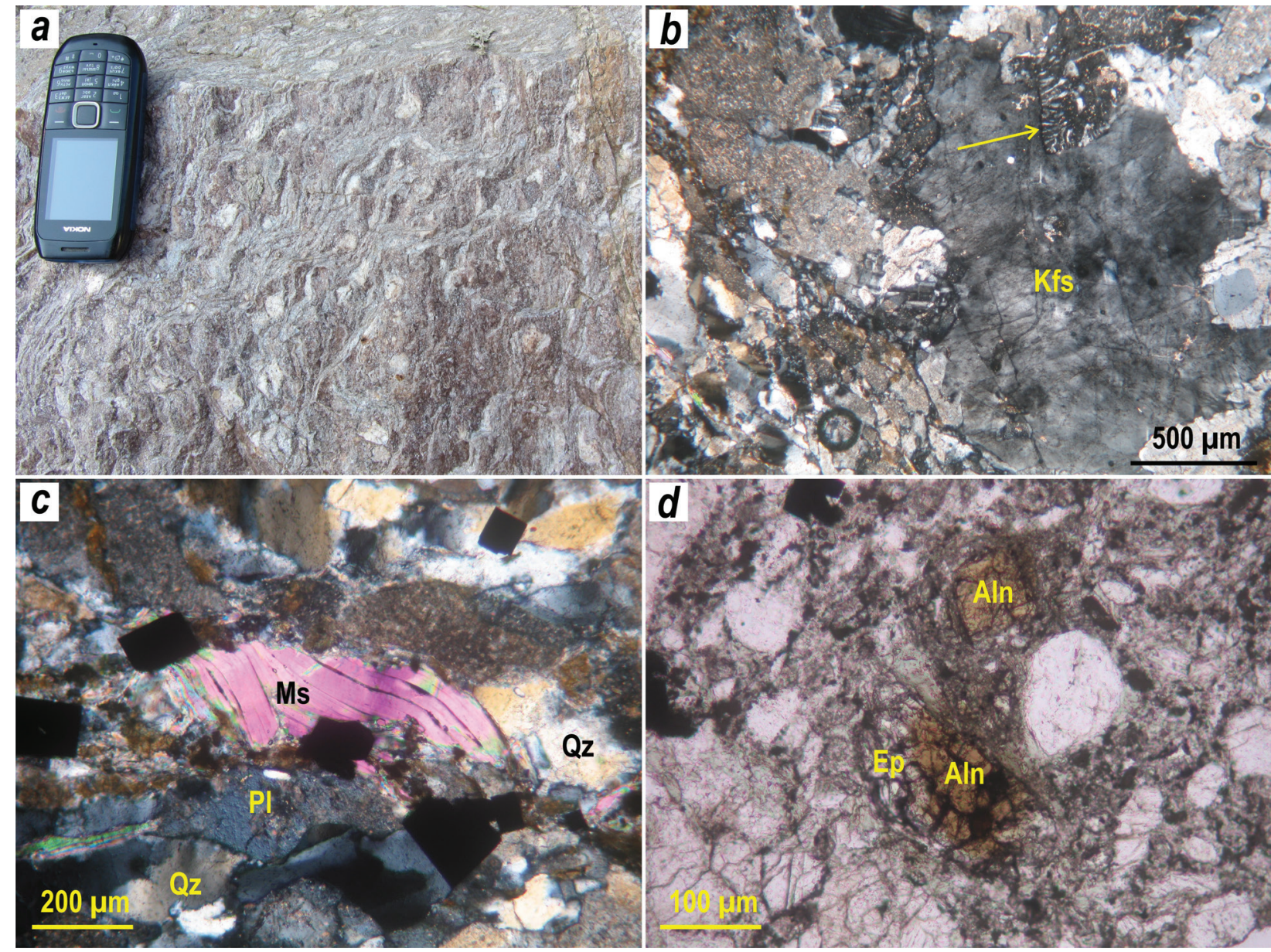

Fig. 2. Field and microphotographs of the Drangovo metagranitoid: a) Typical view of the augen orthogneiss with shear structure; b) Undulatory extinction of the K-feldspar with myrmekites at the edge of the crystal (arrow); $c$ ) Muscovite 'fish' associated with incipient shear bands and plagioclase deformation band; $d$ ) Allanite, rimmed by magmatic epidote.

Abbreviations: Pl - plagioclase, Kfs - potassium feldspar, Ms - muscovite, Qz - quartz, Ep - epidote, Aln - allanite.

\section{U-PB LA-ICPMS ZIRCON GEOCHRONOLOGY RESULTS}

The BSE images of the gneiss zircon grains show either prismatic or rounded to ovoid forms. In CL images, zircons commonly show core-rim structure (Fig. 4a). Their most characteristic feature is that most of the cores are predominantly xenocrystic. The cores are rounded or subrounded, with irregular surfaces or embayment indicative of resorption. Most of them exhibit strong luminescent brightness and great variations in their zonation. Most cores are mantled by thick overgrowths with typical oscillatory zonation, suggesting magmatic growth. A few crystals have planar zonation.

Analytical data and zircon ages are listed in Table 2 and shown in Fig. 4. Four analyses on zircon crystals from the gneiss, mostly from the rims, yield a concordant ${ }^{206} \mathrm{~Pb} /{ }^{238} \mathrm{U}$ age $248.3 \pm 8.9 \mathrm{Ma}$ and MSWD $=1.07$ at $95 \%$ confidence (Fig. $4 b$ ), whereas seven analyses yield a mean ${ }^{206} \mathrm{~Pb} / 238 \mathrm{U}$ age of $251.4 \pm 6.8[2.7 \%]$ and MSWD $=11.4$ at 95\% confidence (Fig. 4c). We interpret the age of $\sim 251 \mathrm{Ma}$ as the emplacement age of the granite. Another eight concordant points from the cores record an inherited component of Carboniferous age $298.6 \pm 2.6 \mathrm{Ma}$ (not shown). Five other analyses on strongly corroded cores yield concordant ages of Devonian, Ordovician to Neo-, Meso-, and Paleoproterozoic ages (Fig. 4d). Two overgrowths yield discordant ages of 52.2 Ma. Interestingly, these ages are similar to the age of the nearby Drangovo pluton (50 Ma; Marchev et al., 2013) and Pripek granites (53 Ma; Ovtcharova, 2003) and are identical to the monazite age of $53 \mathrm{Ma}$ in the Jurassic (146 Ma) deformed pegmatite in the same area (Ovtcharova, 

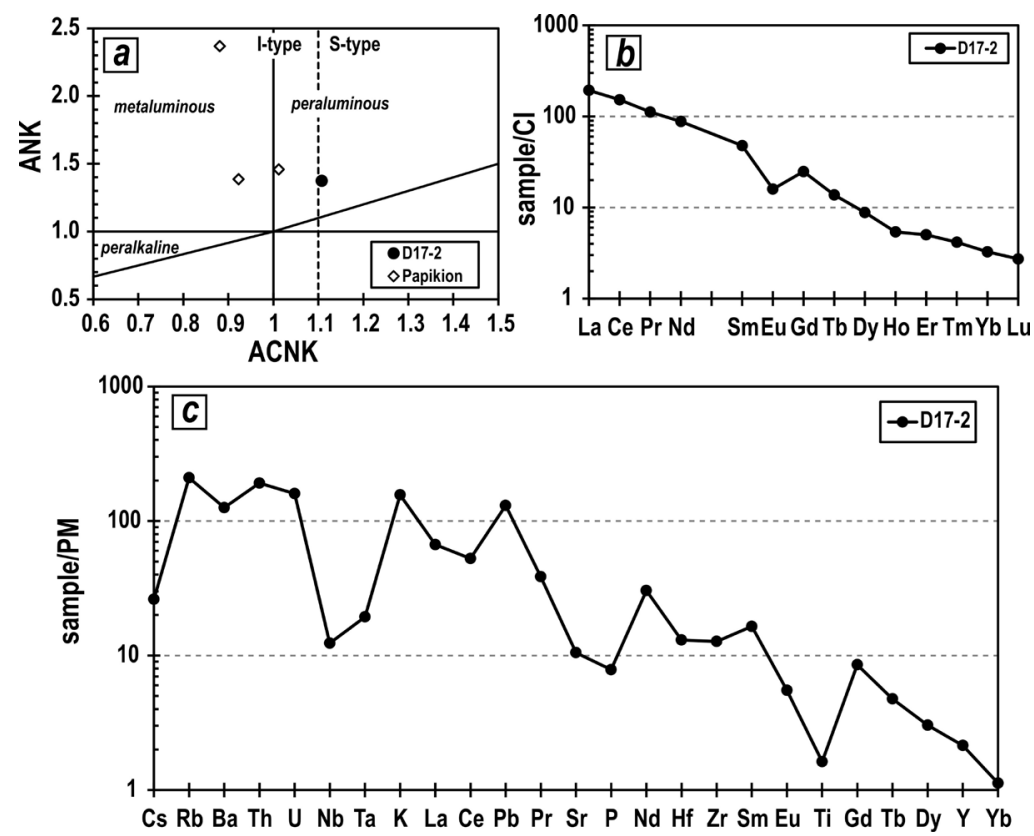

Fig. 3. a) ANK $\left(\mathrm{Al}_{2} \mathrm{O}_{3} /\left(\mathrm{Na}_{2} \mathrm{O}+\mathrm{K}_{2} \mathrm{O}\right)\right.$ molar $)$ vs. $\mathrm{ACNK}\left(\mathrm{Al}_{2} \mathrm{O}_{3} /\left(\mathrm{CaO}+\mathrm{Na}_{2} \mathrm{O}+\mathrm{K}_{2} \mathrm{O}\right)\right.$ molar $)$ diagram for the Drangovo metagranitoid and Papikion pluton; $b$ ) Chondrite-normalized REE pattern; $c$ ) Primitive mantle normalized plots.

2003). We interpret the ages of the rims as a thermal overprint by the higher-temperature early Eocene plutons.

Zircon saturation temperature was used to calculate the crystallization temperatures of the Drangovo gneiss (Watson and Harrison, 1983). The chemistry of the rock meets the critical requirement for the application of this geothermometer: $\mathrm{M}=0.9$ to 1.7 , where $\mathrm{M}=$ cation ratio $(\mathrm{Na}+\mathrm{K}+2 \mathrm{Ca}) /(\mathrm{Al} * \mathrm{Si})$. The calculated $\mathrm{T}_{\mathrm{zr}}$ of $781^{\circ} \mathrm{C}$ belongs to inheritance-rich (cold) granites (Miller et al., 2003). This temperature is similar to the average temperature of $767 \pm$ $14{ }^{\circ} \mathrm{C}$ calculated for the Papikion pluton (Drakoulis et al., 2013) and is also typical for granites from subduction-related or collisional settings.

\section{DISCUSSION}

\section{Age of the P-T magmatism in the Rhodope and Serbo-Macedonian Massifs}

Our $251.4 \pm 6.8 \mathrm{Ma}$ age for the Drangovo gneiss and the age of the nearby Papikion pluton (236 \pm $8 \mathrm{Ma}$ and antecrysts of $250 \mathrm{Ma}$ ) establish the presence of Triassic magmatic activity in the Eastern Rhodopes. The $251.4 \pm 6.8 \mathrm{Ma}$ age of the Drangovo metagranitoid is close to the $253 \pm 13 \mathrm{Ma}$ age of metadiorites from the northern parts of the Western Rhodopes (von Quadt and Peytcheva, 2005), to the 240 Ma age of gneisses from the Central Rhodopes
(Arnaudov et al., 1989), and to the $245.6 \pm 3.9 \mathrm{Ma}$ and $255.8 \pm 2.1$ Ma ages of amphibolitized and/or eclogitized metabasites in the western and eastern parts of the Greek Rhodopes (Liati, 2005). These ages clearly show that P-T magmatism is a regional characteristic feature of the entire Rhodope Massif.

Magmatic products of similar age are widely distributed in the nearby Serbo-Macedonian Massif. For example, the granitic plutons of Kerkini and Arnea from the Greek part yielded ages of $247.0 \pm$ 2.3 Ma (Christophides et al., 2007) and $243 \pm 6$ and $255 \pm 6$ Ma (Poli et al., 2009), respectively. A similar age of $240.2 \pm 1.8$ Ma has been recorded for the Volvi metamafic body intruded in the Arnea granite (Bonev et al., 2018). In the Bulgarian part, the Skrut pluton was dated at $248.85 \pm 0.70 \mathrm{Ma}$ (Zidarov et al., 2007) and the Igralishte granite at $243.3 \pm$ 0.8 Ma (Peytcheva et al., 2009), whereas the Bujanovac pluton from Serbia yielded ages of $255 \pm$ $3 \mathrm{Ma}$ and $253 \pm 2$ Ma (Antić et al., 2016). Clearly, most of the published ages straddle the Permian/Triassic boundary (251 Ma), although some ages suggest that the magmatic activity lasted until $240 \mathrm{Ma}$.

\section{Tectonic environment}

The tectonic setting of the P-T magmatic rocks in the Serbo-Macedonian Massif is still debated, with two distinct models having been proposed. For the granitic Arnea and Kerkini plutons in the Serbo- 

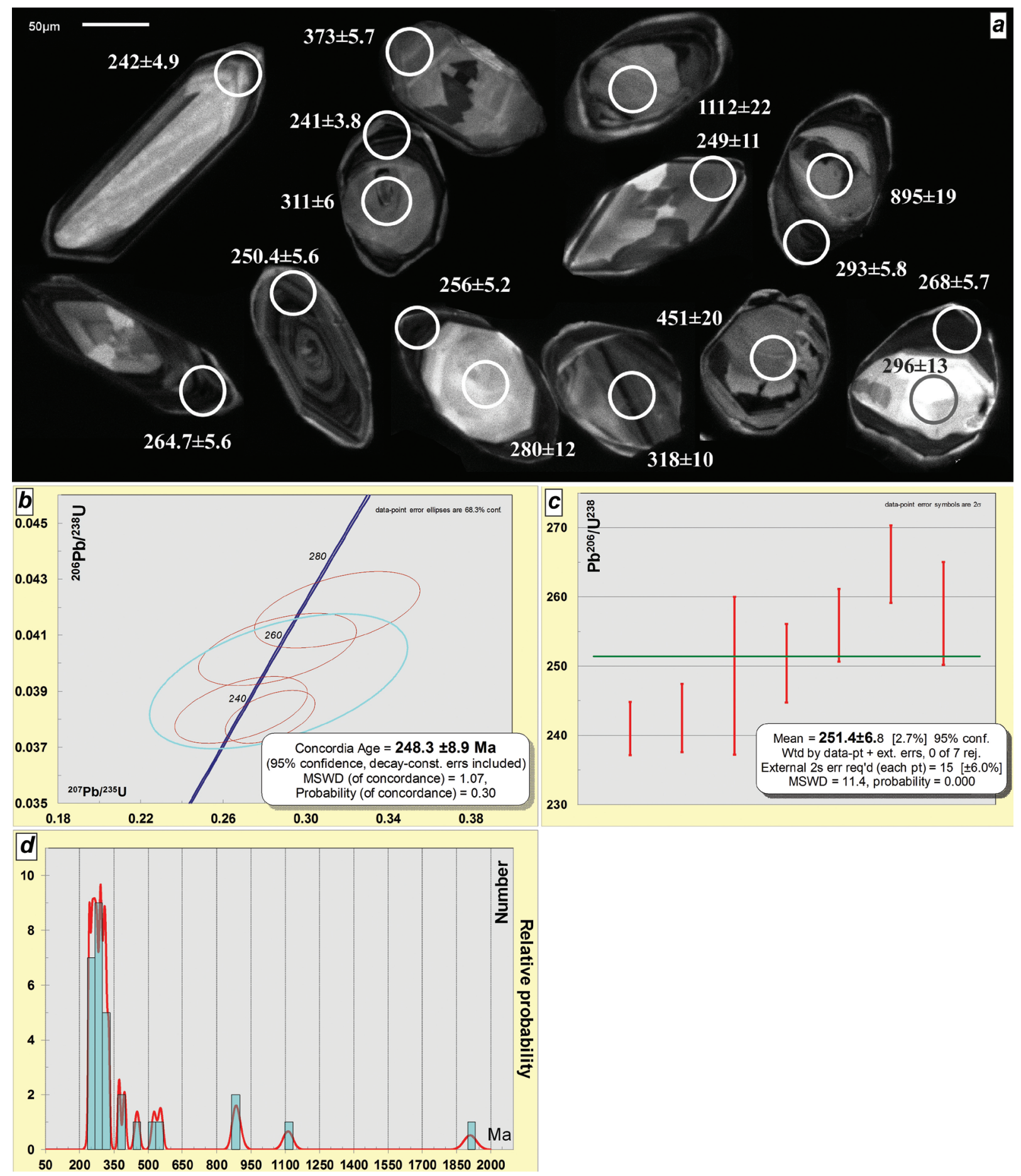

Fig. 4. a) Representative CL images of zircons from the Drangovo metagranitoid. Zircons commonly show xenocrystic cores rimmed by a zoned magmatic outer rim; $b$ ) U/Pb concordia plot of the P-T zircons; $c$ ) Mean age plot; $d$ ) Probability density diagram showing age distribution of magmatic and xenocrystic zircons from the Drangovo metagranitoid. Note distinct age peaks at 251 Ma and $299 \mathrm{Ma}$.

Macedonian massif, Christofides et al. (1999) and Himmercus et al. (2009) suggested rift-related A-type affinity of the magmatism related to the opening of the Meliata-Vardar Ocean. Similarly, Bonev et al. (2018) proposed rift-related formation of Therma Volvi and the Gomati mafic-ultramafic bodies and bimodal rift-related comagmatic origin of the entire P-T Serbo-Macedonian and Rhodope magmatism. Conversely, Poli et al. (2009) concluded that the Arnea and Kerkini granites are 
Table 2

$\mathrm{U}(-\mathrm{Th})-\mathrm{Pb}$ isotope data of zircons from the Drangovo metagranitoid

\begin{tabular}{|c|c|c|c|c|c|c|c|c|c|c|c|c|c|c|}
\hline \multirow{2}{*}{ Analysis\# } & \multirow{2}{*}{ grain } & \multicolumn{8}{|c|}{ Isotope ratios } & \multirow{2}{*}{ Rho } & \multicolumn{4}{|c|}{ Age (Ma) } \\
\hline & & ${ }^{207} \mathrm{~Pb} /{ }^{206} \mathrm{~Pb}$ & 1SE & ${ }^{206} \mathrm{~Pb} /{ }^{238} \mathrm{U}$ & $1 \mathrm{SE}$ & ${ }^{207} \mathrm{~Pb} /{ }^{235} \mathrm{U}$ & 1SE & ${ }^{208} \mathrm{~Pb} /{ }^{232} \mathrm{Th}$ & 1SE & & ${ }^{206} \mathrm{~Pb} /{ }^{238} \mathrm{U}$ & $1 \mathrm{SE}$ & ${ }^{207} \mathrm{~Pb} /{ }^{235} \mathrm{U}$ & 1SE \\
\hline 13ос31с13 & $2 \mathrm{r}$ & 0.05082 & 0.00409 & 0.03834 & 0.00079 & 0.26867 & 0.02124 & 0.01520 & 0.00195 & 0.56 & 242.5 & 4.9 & 241.6 & 17.0 \\
\hline 13ос31с14 & $3 r$ & 0.05262 & 0.00405 & 0.04943 & 0.00098 & 0.35858 & 0.02715 & 0.01804 & 0.00199 & 0.56 & 311.0 & 6.0 & 311.2 & 20.3 \\
\hline 13ос31с15 & $4 \mathrm{cr}$ & 0.05643 & 0.00284 & 0.05955 & 0.00094 & 0.46329 & 0.02308 & 0.02622 & 0.00242 & 0.57 & 372.9 & 5.7 & 386.5 & 16.0 \\
\hline 13ос31с16 & $5 r$ & 0.05383 & 0.00277 & 0.03809 & 0.00062 & 0.28271 & 0.01433 & 0.01293 & 0.00133 & 0.57 & 241.0 & 3.8 & 252.8 & 11.3 \\
\hline 13ос31с17 & $5 c$ & 0.05756 & 0.00373 & 0.04997 & 0.00088 & 0.39658 & 0.02534 & 0.01776 & 0.00191 & 0.56 & 314.3 & 5.4 & 339.2 & 18.4 \\
\hline 13ос31с18 & $6 \mathrm{r}$ & 0.10563 & 0.01765 & 0.00812 & 0.00031 & 0.11831 & 0.01932 & 0.00908 & 0.00156 & 0.56 & 52.2 & 2.0 & 113.5 & 17.5 \\
\hline 13ос31с19 & $8 \mathrm{r}$ & 0.05288 & 0.00208 & 0.05198 & 0.00075 & 0.37902 & 0.01486 & 0.01415 & 0.00165 & 0.58 & 326.7 & 4.6 & 326.3 & 10.9 \\
\hline 13ос31с20 & $7 \mathrm{c}$ & 0.10665 & 0.01198 & 0.04076 & 0.00120 & 0.59944 & 0.06564 & 0.02036 & 0.00278 & 0.56 & 257.6 & 7.4 & 476.9 & 41.7 \\
\hline 13 ос31d03 & & 0.05758 & 0.00375 & 0.05386 & 0.00093 & 0.42763 & 0.02740 & 0.01514 & 0.00269 & 0.56 & 338.2 & 5.7 & 361.5 & 19.5 \\
\hline 13ос31d04 & 1'r & 0.05453 & 0.00468 & 0.04191 & 0.00090 & 0.31515 & 0.02653 & 0.01786 & 0.00330 & 0.56 & 264.7 & 5.6 & 278.2 & 20.5 \\
\hline 13ос31d05 & 2' r & 0.05242 & 0.00349 & 0.04850 & 0.00085 & 0.35060 & 0.02300 & 0.01356 & 0.00210 & 0.56 & 305.3 & 5.2 & 305.2 & 17.3 \\
\hline 13ос31d06 & 3' r & 0.05137 & 0.00447 & 0.03332 & 0.00069 & 0.23607 & 0.02019 & 0.02857 & 0.00723 & 0.56 & 211.3 & 4.3 & 215.2 & 16.6 \\
\hline 13ос31d07 & 4' cr & 0.06831 & 0.01408 & 0.03932 & 0.00184 & 0.37043 & 0.07465 & 0.01191 & 0.00241 & 0.56 & 248.6 & 11.4 & 320.0 & 55.3 \\
\hline 13ос31d08 & $5^{\prime} \mathrm{r}$ & 0.05123 & 0.00460 & 0.04050 & 0.00085 & 0.28616 & 0.02528 & 0.02175 & 0.00431 & 0.56 & 255.9 & 5.2 & 255.5 & 20.0 \\
\hline 13ос31d09 & 5' c & 0.05230 & 0.01882 & 0.04438 & 0.00203 & 0.32005 & 0.11436 & 0.01076 & 0.00233 & 0.53 & 279.9 & 12.5 & 281.9 & 88.0 \\
\hline 13 oc $31 \mathrm{~d} 10$ & $6^{\prime} \mathrm{c}$ & 0.05213 & 0.00915 & 0.05060 & 0.00163 & 0.36380 & 0.06302 & 0.01528 & 0.00419 & 0.55 & 318.2 & 10.0 & 315.1 & 46.9 \\
\hline 13ос31d13 & $8^{\prime} \mathrm{r}$ & 0.05160 & 0.00851 & 0.03208 & 0.00098 & 0.22831 & 0.03711 & 0.09174 & 0.03763 & 0.55 & 203.6 & 6.1 & 208.8 & 30.7 \\
\hline 13ос31d14 & 8' c & 0.06846 & 0.00452 & 0.14638 & 0.00271 & 1.38218 & 0.08929 & 0.03692 & 0.00756 & 0.57 & 880.7 & 15.2 & 881.4 & 38.1 \\
\hline 13 oc31d15 & 9' c & 0.07296 & 0.00674 & 0.14861 & 0.00345 & 1.49533 & 0.13517 & 0.03854 & 0.00830 & 0.56 & 893.2 & 19.4 & 928.5 & 55.0 \\
\hline 13ос31d16 & $9^{\prime} \mathrm{r}$ & 0.05438 & 0.00471 & 0.04648 & 0.00094 & 0.34856 & 0.02961 & 0.01557 & 0.00681 & 0.56 & 292.9 & 5.8 & 303.6 & 22.3 \\
\hline 13ос31d17 & $10^{\prime} \mathrm{c}$ & 0.05218 & 0.00456 & 0.04606 & 0.00095 & 0.33148 & 0.02835 & 0.01276 & 0.00289 & 0.56 & 290.3 & 5.8 & 290.7 & 21.6 \\
\hline 13ос31d18 & $11^{\prime} \mathrm{c}$ & 0.08452 & 0.00652 & 0.18825 & 0.00399 & 2.19399 & 0.16479 & 0.05560 & 0.01319 & 0.57 & 1111.9 & 21.7 & 1179.1 & 52.4 \\
\hline 13ос31d19 & $12^{\prime} \mathrm{r}$ & 0.07077 & 0.00666 & 0.03961 & 0.00091 & 0.38651 & 0.03549 & 0.03723 & 0.01029 & 0.56 & 250.4 & 5.7 & 331.8 & 26.0 \\
\hline 13ос31d20 & $14^{\prime} \mathrm{C}$ & 0.05601 & 0.00671 & 0.07246 & 0.00175 & 0.55961 & 0.06593 & 0.02592 & 0.00731 & 0.55 & 451.0 & 10.5 & 451.3 & 42.9 \\
\hline 13ос31e03 & $15^{\prime} \mathrm{r}$ & 0.05512 & 0.00493 & 0.04240 & 0.00093 & 0.32225 & 0.02824 & 0.01769 & 0.01124 & 0.56 & 267.7 & 5.8 & 283.6 & 21.7 \\
\hline 13ос31e04 & $15^{\prime} \mathrm{c}$ & 0.04905 & 0.02451 & 0.04705 & 0.00215 & 0.31827 & 0.15847 & 0.01192 & 0.00198 & 0.52 & 296.4 & 13.2 & 280.6 & 122.1 \\
\hline 13ос31e05 & $16^{\prime} \mathrm{r}$ & 0.07523 & 0.02228 & 0.00812 & 0.00036 & 0.08428 & 0.02470 & -0.00241 & 0.01153 & 0.54 & 52.2 & 2.3 & 82.2 & 23.1 \\
\hline 13ос31e06 & $16^{\prime} \mathrm{c}$ & 0.13388 & 0.00692 & 0.34470 & 0.00584 & 6.36379 & 0.32226 & 0.09487 & 0.01348 & 0.58 & 1909.3 & 28.0 & 2027.3 & 44.4 \\
\hline 13ос31e07 & $17^{\prime} \mathrm{cr}$ & 0.06040 & 0.00397 & 0.04361 & 0.00076 & 0.36322 & 0.02341 & 0.01307 & 0.00197 & 0.56 & 275.2 & 4.7 & 314.6 & 17.4 \\
\hline 13ос31e08 & $19^{\prime}$ c & 0.11801 & 0.04502 & 0.04533 & 0.00296 & 0.73771 & 0.27761 & 0.01124 & 0.00300 & 0.54 & 285.8 & 18.3 & 561.1 & 162.2 \\
\hline 13ос31e09 & $21^{\prime} \mathrm{c}$ & 0.03838 & 0.02050 & 0.04570 & 0.00223 & 0.24183 & 0.12871 & 0.01343 & 0.00259 & 0.52 & 288.0 & 13.8 & 219.9 & 105.2 \\
\hline 13ос31e10 & $20^{\prime} \mathrm{r}$ & 0.06350 & 0.00453 & 0.08977 & 0.00167 & 0.78609 & 0.05486 & 0.03499 & 0.00631 & 0.56 & 554.2 & 9.9 & 589.0 & 31.2 \\
\hline 13ос31e11 & $23^{\prime} \mathrm{cr}$ & 0.06150 & 0.00439 & 0.06331 & 0.00114 & 0.53693 & 0.03748 & 0.02623 & 0.00515 & 0.56 & 395.7 & 6.9 & 436.4 & 24.8 \\
\hline 13ос31e12 & $24^{\prime} \mathrm{c}$ & 0.09465 & 0.02518 & 0.04532 & 0.00207 & 0.59149 & 0.15525 & 0.01689 & 0.00366 & 0.54 & 285.7 & 12.7 & 471.8 & 99.1 \\
\hline 13ос31e13 & $25^{\prime} \mathrm{r}$ & 0.06212 & 0.00959 & 0.03510 & 0.00116 & 0.30070 & 0.04549 & 0.04398 & 0.01332 & 0.55 & 222.4 & 7.2 & 266.9 & 35.5 \\
\hline 13ос31e14 & $25^{\prime} \mathrm{c}$ & 0.06375 & 0.00561 & 0.08493 & 0.00180 & 0.74661 & 0.06419 & 0.02958 & 0.00719 & 0.56 & 525.5 & 10.7 & 566.3 & 37.3 \\
\hline
\end{tabular}

Abbreviations refer to: $\mathrm{r}$ - rim; c - core; $\mathrm{rc}$ - rim and core part; Rho - correlation coefficient ${ }^{206} \mathrm{~Pb} /{ }^{238} \mathrm{U}-{ }^{207} \mathrm{~Pb} /{ }^{235} \mathrm{U}$

A2-subtype indicating that the magmatism is more likely to be connected to an orogenic extensional environment than to an intra-plate rifting. Interpretations for the tectonic setting of the granites on the Bulgarian side of the Serbo-Macedonian Massif are in favor of a volcanic-arc to syn-collisional environment (Zidarov et al., 2007; Peytcheva et al., 2009). Drakoulis et al. (2013) suggest a similar setting for the Papikion pluton from the Eastern Rhodopes.

A detailed discussion on the geodynamic setting of the magmatism in the entire region is beyond the scope of this report. Our single age is not enough to unravel the tectonic setting of the magmatism in the Eastern Rhodopes. However, age similarity and subduction-related signatures of both the metagranitoid from Drangovo and the nearby Papikion granitoids can be interpreted in favor of origin in a similar tectonic setting. On the other hand, the large amount of xenocrystic zircons from the underlying basement suggest the presence of a comparatively thick crust at the time of this magmatism and do not offer support for crustal thinning accompany- 
ing rifting. Additional studies are needed to better clarify the geodynamic setting of the region during the P-T transition.

\section{Genesis}

Different suggestions have been made for the genesis of the P-T granitoids in the Serbo-Macedonian and Rhodope Massifs: (1) crustal melting caused by underplating of basaltic melts below the incipient rift (Poli et al., 2009; Peytcheva et al., 2009; Himmerkus et al., 2009); (2) extensive crustal contamination of juvenile mafic magma that originated from depleted mantle (Zidarov et al., 2007; Antić et al., 2016); and (3) fluid-absent melting of a biotiterich tonalitic source (Christofides et al., 2007).

The suggestions for the origin of P-T granites from crustal melting caused by basaltic melts is based on the relatively high initial $\mathrm{Sr}$ isotopic ratios obtained for the Kerkini granite $(0.7112$ to 0.7202 - Christofides et al., 2007; 0.7136 to 0.7187 Himmerkus et al., 2009) and the Arnea granite (0.7142 - Himmerkus et al., 2009). Poli et al. (2009) attributed the high initial Sr isotopic ratios to hydrothermal alteration and post-intrusive metamorphic and deformational processes of the Arnea granite. They argued that the very high $\mathrm{Rb} / \mathrm{Sr}$ ratio, and an aberrant age used by Himmerkus et al. (2009), led to calculation of the very high initial ratios for the Kerkini granite. Nevertheless, Poli et al. (2009) proposed crustal melting by mantle melts penetrating or underplating the crust. A similar origin was proposed for the nearby Igralishte pluton by Peytcheva et al. (2009). Unlike the previous suggestions, however, these authors proposed a mixed mantle-crustal origin of the granite on the basis of the lower initial Sr isotopic values of the rocks (0.7078).

The hypothesis for crustal contamination of the juvenile mafic magma is based mostly on the pres- ence of the large number of xenocrystic zircons, and highly positive $\varepsilon \mathrm{Hf}(+0.4$ to +3.5$)$ of the autocrystic zircons in the Skrut pluton (Zidarov et al., 2007). Involvement of a mantle component in the genesis and evolution of the Papikion pluton was also proposed by Drakoulis et al. (2013) based on the presence of basic rocks in the pluton.

Our preliminary data for the Drangovo metagranitoid are too limited to discuss in detail the genesis of the rock. However, we note that the presence of large amount of xenocrystic zircons rules out the pure mantle-derived origin of the magmas and demonstrates the extensive involvement of older basement rocks for the Permian-Triassic metamorphosed granitoids.

\section{CONCLUSIONS}

1) Ages of metagranitoid from the Bulgarian part of the Kessebir dome, along with the Papikion pluton from the Greek part, suggest that PermoTriassic magmatism is present in the Eastern Rhodopes.

2) The Drangovo metagranitoid and Papikion granitoids have subduction-related signatures and were more likely formed in a volcanic-arc to syn-collisional tectonic setting.

\section{Acknowledgements}

Richard Conrey (Hamilton College) is thanked for the XRF analyses. Discussion with Svet Georgiev (Colorado State University) and Richard Conrey helped us to improve the manuscript and polish the English. We wish to thank three anonymous reviewers for their constructive reviews and suggestions, which improved an early version of the manuscript.

\section{REFERENCES}

Antić, M., Peytcheva, I., von Quadt, A., Kounov, A., Trivić, B., Serafimovski, T., Tasev, G., Gerdjikov, I., Wetzel, A. 2016. Pre-Alpine evolution of a segment of the North-Gondwanan margin: Geochronological and geochemical evidence from the central Serbo-Macedonian Massif. Gondwana Research 36, 523-544.

Arnaudov, V., Amov, B., Bartnitskiy, E., Pavlova, M. 1989. Isotope geochronology of magmatic and metamorphic rocks of the Balkanides and Rhodope massif. XIV Congress CBGA, Sofia, Extended abstracts, 1154-1157.

Bonev, N., Ovtcharova-Schaltegger, M., Moritz, R., Marchev, P., Ulianov, A. 2013. Peri-Gondwanan Ordovician crustal fragments in the high-grade basement of the Eastern Rhodope Massif, Bulgaria: evidence from U-Pb LA-ICP-MS zircon geochronology and geochemistry. Geodinamica Acta 26 (3-4), 207-229 
Bonev, N., Moritz, R., Borisova, M., Filipov, P. 2018. ThermaVolvi-Gomati complex of the Serbo-Macedonian Massif, northern Greece: a Middle Triassic continental margin ophiolite of Neotethyan origin. Journal of the Geological Society, doi: 10.1144/jgs2017-130.

Christofides, G., Koroneos, A., Liati, A., Kral, J. 2007. The A-type Kerkini granitic complex in northern Greece: Geochronology and geodynamic implications. Bulletin of the Geological Society of Greece 40, 700-711.

Christofides, G., Koroneos, A., Pe-Piper, G., Katirtzoglou, K., Chatzikirkou, A. 1999. Pre-Tertiary A-Type magmatism in the Serbomacedonian massif (N. Greece): Kerkini granitic complex. Bulletin of the Geological Society of Greece 33, 131-48.

Drakoulis, A., Koroneos, A., Poli, G., Soldatos, T., Papadopoulou, L., Murata, M., Eliwa, H. 2013. U-Pb zircon dating of the Mt. Papikion pluton (Central Rhodope, Greece): New constraints on the evolution of Kessebir-Kardamos Dome. Acta Vulcanologica 25 (1-2), 83-98.

Himmerkus, F., Reischmann, T., Kostopoulos, D. 2009. Triassic rift-related meta-granites in the Internal Hellenides, Greece. Geological Magazine 146 (2), 252-265.

Liati, A. 2005. Identification of repeated Alpine (ultra) highpressure metamorphic events by U-Pb SHRIMP geochronology and REE geochemistry of zircon: the Rhodope zone of Northern Greece. Contributions to Mineralogy and Petrology 150, 608-630.

Ludwig, K. R. 2003. User's manual for Isoplot 3.00. A Geochronological Toolkit for Microsoft Excel. Berkeley Geochronology Center Special Publication, p. 4.

Marchev, P., Georgiev, S., Raicheva, R., Peytcheva, I., von Quadt, A., Ovtcharova, M., Bonev, N. 2013. Adakitic magmatism in post-collisional setting: an example from the Early-Middle Eocene Magmatic Belt in South Bulgaria and North Greece. Lithos 180-181, 159-180.

Miller, C.F., Meschter-McDowell, S., Mapes, R.W. 2003. Hot and cold granites? Implications of zircon saturation temperatures and preservation of inheritance. Geology 31 (6), 529-532.

Nedialkov, R., Belmustakova, H., Ovtcharova, M., Popov, M. 1998. Petrology of the Drangovo pluton, Central Rhodopes. Geochemistry, Mineralogy and Petrology 34, 111-124 (in Bulgarian, with English abstract).

Ovtcharova, M. 2003. Petrology, geochronology and isotopic studies of the metagranitoids from the eastern part of the
Madan-Davidkovo dome. PhD Thesis, Sofia University, 235 pp. (in Bulgarian).

Peytcheva, I., Ovtcharova, M., Sarov, S., Kostitsin, Y. 1998. Age and metamorphic evolution of metagranites from Kessebir reka region, Eastern Rhodopes - Rb-Sr isotope data. Proceedings of the XVI CBGA Congress, Austria, Vienna, 471-472.

Peytcheva, I, von Quadt, A., Tarassov, M., Zidarov, N., Tarassova, E., Andreichev, A. 2009. Timing of Igralishte pluton in Ograzhden Mountain, SW Bulgaria: implications for the tectono-magmatic evolution of the region. Geologica Balcanica 38 (1-3), 5-14.

Poli, G., Christofides, G., Koroneos, A., Soldatos, T., Perugini, D., Lagone, A. 2009. Early Triassic granitic magmatism Arnea and Kerkini granitic complexes - in the Vertiskos unit (Serbo-macedoniam massif, north-eastern Greece) and its significance in the geodynamic volution of the area. Acta Vulcanologica 20-21, 47-70.

Ricou, L.-E., Burg, J.-P., Godfriaux, I., Ivanov, Z.1998. Rhodope and Vardar: the metamorphic and the olistostromic paired belts related to the Cretaceous subduction under Europe. Geodinamica Acta 11 (6), 1-25.

Sarov, S., Yordanov, B., Valkov, V., Georgiev, St., Kalinov, I., Kamburov, D., Raeva, E., Voynova, E., Ovtcharova, M., Kuncheva, B., Grozdev, V., Balkanska, E., Moskovska, L., Dobrev, G. 2008. Geological map of the Republic of Bulgaria in scale 1:50 000, K-35-87-G (Dzhebel) and K-35-99-B (Kirkovo) map sheets. Ministry of Environment and Waters, Bulgarian National Geological Survey, Sofia.

von Quadt, A., Peytcheva, I. 2005. The southern extension of the Srednogorie type Upper Cretaceous magmatism in Rila-Western Rhodopes: constraints from isotope-geochronological and geochemical data. Bulgarian Geological Society, Jubilee Conference with International Participation "80 years Bulgarian Geological Society”, Abstracts, 113-116.

Watson, E.B., Harrison, T.M. 1983. Zircon saturation revisited: Temperature and composition effects in a variety of crustal magma types. Earth and Planetary Science Letters 64, 295-304.

Zidarov, N., Tarassova, E., Peytcheva, I., von Quadt, A., Andreichev, V., Titorenkova, R. 2007. Petrology, geochemistry and age dating of Skrut granitoids - new evidence for Early Triassic magmatism in Belasitsa Mountain (SW Bulgaria). Geologica Balcanica 36 (1-2), 17-29. 